\title{
A study on influencing factors on brand loyalty: A case study of Mobile industry
}

\author{
Bahman Dehestani $^{a^{*}}$, Nadereh Sadat Najafi Zadeh ${ }^{\mathrm{b}}$ and Iraj Noori ${ }^{\mathrm{b}}$
}

${ }^{a}$ M.A. in Marketing, Management Department, Arak Branch, Islamic Azad University, Arak, Iran ${ }^{b}$ Member of Management Department, Arak Branch, Islamic Azad University, Arak, Iran

\section{H R O N I C L E}

Article history:

Received January 12, 2013

Received in revised format

30 May 2013

Accepted 5 June 2013

Available online

June 92013

Keywords:

Brand loyalty

Brand equity

Advertisement intensity

Brand awareness

\begin{abstract}
A B S T R A C T
Brand loyalty plays essential role on product development especially in mobile industry. In this paper, we present an empirical survey to study the effects of different factors including brand associate, brand awareness, distribution intensity and quality perception on brand loyalty. The proposed model of this paper is examined by designing a questionnaire consists of 16 questions in Likert scale and distributing it among 200 people who use a particular brand in mobile industry called Nokia. The results are analyzed using structural equation modeling where Cronbach alpha is calculated as 0.84 . The results indicate that there is a positive relationship between perception quality as well as brand awareness and brand loyalty. In addition, there is a positive relationship between brand awareness and perception quality.
\end{abstract}

(C) 2013 Growing Science Ltd. All rights reserved.

\section{Introduction}

Brand loyalty plays essential role on product development especially in mobile industry and there are literally different studies accomplished on detecting the effects of different factors on brand equity. According to Zehir et al. (2011), Brands play essential role in the consumer markets and brands are considered as the interface between consumers and the company, and consumers may develop trust and loyalty to brands. Zehir et al. (2011) investigated the impacts of brand communication and service quality in building brand loyalty through brand trust. They explored the relationship among brand communication and service quality in a relational context with an emphasis on getting insights of the linking role of brand trust and loyalty and they applied their model on automotive industry in Turkey. They reported that perceptions of brand communications and service/product quality could be viewed an antecedents to brand trust, in turn influences brand loyalty. 
Yoo et al. (2000) investigated the relationships between selected marketing mix elements and the creation of brand equity. They proposed a conceptual framework in which marketing elements were associated with the dimensions of brand equity, that is, perceived quality, brand loyalty, and brand associations combined with brand awareness. These dimensions are then linked to brand equity. The empirical tests using a structural equation model supported their research hypotheses and they reported that frequent price promotions, such as price deals, were associated with low brand equity, whereas high advertising spending, high price, good store image, and high distribution intensity are related to high brand equity.

Valkenburg and Buijzen (2005) identified determinants of young children's brand awareness: television, parents, and peers. Usman et al. (2010) examined cultural effects on the general attitude of Pakistani people towards advertising. They analyzed the cultural effect on attitude of people towards advertisements of brands based on product information, social integration and hedonism/pleasure, whereas power distance and masculinity as culture dimensions. They reported that social integration, product information and hedonism had a significant effect on attitude towards advertisement. However, product information had weak effect on attitude towards advertisement; whereas culture had a substantial moderating impact.

Tepeci (1999) performed an investigation on factors, which contribute to brand loyalty in marketing literature and provides strategies to hospitality managers for increasing brand loyal customers. Sahin et al. (2011) conducted with actual consumers, addressed the question whether various consumers prefer various experiential appeals and whether experiential kinds create the relationships between brand experiences, satisfaction, trust and loyalty. Brand experience was conceptualized as sensations, feelings, cognitions, and behavioral responses evoked by brand-related stimuli, which were part of a brand's design and identity, packaging, communications, and environments. They proposed the impacts of brand experiences on build long-lasting brand and customer relationship with brand trust, satisfaction, and loyalty.

Romaniuk and Nenycz-Thiel (2013) reported that applying competitors could have a bigger dampening impact on brand associations than the reinforcement impact of repeated brand buying. The results also represent important implications for modeling brand associations, particularly using cross-sectional data. Ling et al. (2010) investigated the determinants of consumers' behavior towards advertising among tertiary students in a private higher education institution in Malaysia. They reported that credibility, informative, hedonic/ pleasure and good for economy were positively associated with consumers' attitude towards advertising. Lee and Back (2010) reexamined attendeebased brand equity by additionally sampling regional CHRIE conferences (RCs) and comparing the data with I-CHRIE's annual conference (IC) in the context of their theoretical model. According to Lassar et al. (1995), brand equity plays important role for marketers of consumer goods and services. Brand equity could facilitate in the effectiveness of brand extensions and brand introductions and this is because consumers who trust and display loyalty towards a brand are willing to attempt to adopt brand extensions. Field et al. (2012) determined the extent that extrinsic product attributes (brand name/packaging) impact consumers' perceptions and resulting evaluation of intrinsic product attributes, quality, and purchase intention. They reported that store brand managers must increase the quality of their product if they expect to capture market share from the national brands. Chen (2001) examined the relationship between the characteristics of brand associations and brand equity using free association. Buil et al. (2013) explored the relationships between two central elements of marketing communication programs, advertising and sales promotions, and their effects on brand equity creation. More specifically, the research concentrated on advertising spend and individuals' behaviors toward the advertisements. The study also investigated the impacts of two types of sales promotions, monetary and non-monetary promotions. They reported distinctive impacts of monetary and non-monetary promotions on brand equity. 


\section{The proposed method}

The proposed model of this paper uses a model, which is stated in Fig. 1 as follows,

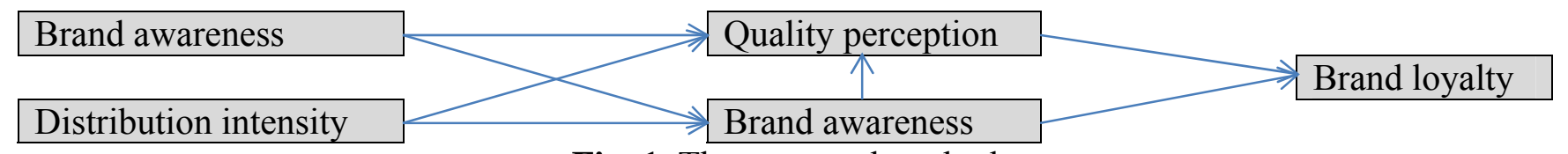

Fig. 1. The proposed method

The proposed study uses structural equation modeling (SEM) to study the relationship between different components of the study. There are seven hypotheses associated with the proposed study of this paper as follows,

1. There is a positive relationship between perception quality and brand loyalty.

2. There is a positive relationship between brand awareness and brand loyalty.

3. There is a positive relationship between brand awareness and perception quality.

4. There is a positive relationship between brand awareness and brand associate.

5. There is a positive relationship between perception quality and brand associate.

6. There is a positive relationship between brand awareness and distribution intensity.

7. There is a positive relationship between perception quality and distribution intensity.

The proposed study of this paper uses a questionnaire consists of 16 questions in Likert scale. In our survey, the first three questions are associated with brand loyalty, the next 4 questions are related to brand awareness, the next five questions are associated with quality perception, 2 questions are devoted to brand associate and finally, the last two questions are dedicated to distribution intensity. The proposed study distributes 200 questionnaires among participants. Cronbach alpha has been calculated as 0.84 , which is well above the minimum acceptable limit. In addition, Cronbach alpha for brand loyalty, brand awareness, quality perception, brand association and distribution intensity are $0.77,82.3,81.3,81.6$ and 85.6 percent, respectively. The results of implementation of SEM on LISREL software package are summarized in Table 1 as follows,

\section{Table 1}

The summary of different statistics associated with the implementation of SEM

\begin{tabular}{llll}
\hline Index & Value & Index & Value \\
\hline Degrees of Freedom & 96 & GFI & 0.87 \\
Chi-Square & 237.91 & CFI & 0.97 \\
Chi-Square/df & 2.28 & IFI & 0.97 \\
SRMR & 0.082 & RMSEA & 0.082 \\
\hline
\end{tabular}

The results of Table 1 verify the overall questionnaire and we can interpret the results. Fig. 2 and Fig. 3 demonstrate the results of standard values and t-student values, respectively. Table 2 summarizes the results of SEM.

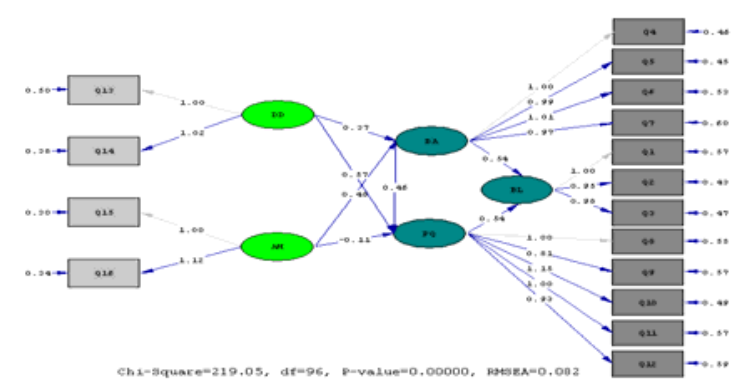

Fig. 2. The results of standard values

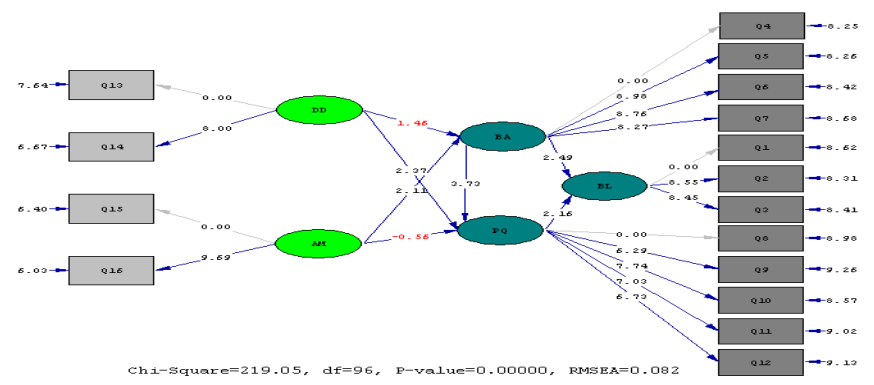

Fig. 3. The results of t-student values 


\section{Table 2}

The results of structural equation modeling in terms of different questions

\begin{tabular}{cccccc}
\hline Variable & Question & Parameter & Coefficient & Error & t-student \\
\hline \multirow{3}{*}{ Brand loyalty } & Q1 & $\lambda y_{1}$ & 1 & - & - \\
& Q2 & $\lambda y_{2}$ & 0.95 & 0.11 & 8.55 \\
& Q3 & $\lambda y_{3}$ & 0.98 & 0.12 & 8.45 \\
\hline \multirow{5}{*}{ Brand awareness } & Q4 & $\lambda y_{4}$ & 1 & - & - \\
& Q5 & $\lambda y_{5}$ & 0.99 & 0.11 & 8.98 \\
& Q6 & $\lambda y_{6}$ & 1.01 & 0.12 & 8.76 \\
& Q7 & $\lambda y_{7}$ & 0.97 & 0.12 & 8.27 \\
\hline \multirow{2}{*}{ Quality } & Q8 & $\lambda y_{8}$ & 1 & - & - \\
& Q9 & $\lambda y_{9}$ & 0.81 & 0.13 & 6.29 \\
& Q10 & $\lambda y_{10}$ & 1.15 & 0.15 & 7.74 \\
\hline \multirow{2}{*}{ Advertisement } & Q11 & $\lambda y_{11}$ & 1 & 0.14 & 7.03 \\
\hline Distribution & Q12 & $\lambda y_{12}$ & 0.93 & 0.14 & 6.73 \\
\hline intensity & Q13 & $\lambda x_{1}$ & 1 & - & - \\
\hline
\end{tabular}

In addition, Table 3 demonstrates the results of testing seven hypotheses of this survey. As we can observe from the results of Table 3, only two hypotheses are not confirmed and five other hypotheses have been confirmed.

\section{Table 3}

The summary of testing seven hypotheses

\begin{tabular}{|c|c|c|c|c|}
\hline Row & & Coefficient & t-value & Result \\
\hline 1 & $\begin{array}{l}\text { There is a positive relationship between quality perception and brand } \\
\text { loyalty. }\end{array}$ & 0.54 & 2.16 & $\sqrt{ }$ \\
\hline 2 & $\begin{array}{l}\text { There is a positive relationship between brand awareness and brand } \\
\text { loyalty. }\end{array}$ & 0.54 & 2.49 & $\sqrt{ }$ \\
\hline 3 & $\begin{array}{l}\text { There is a positive relationship between brand awareness and quality } \\
\text { perception. }\end{array}$ & 0.46 & 3.73 & $\sqrt{ }$ \\
\hline 4 & $\begin{array}{l}\text { There is a positive relationship between brand awareness and brand } \\
\text { associate. }\end{array}$ & 0.37 & 1.46 & $x$ \\
\hline 5 & $\begin{array}{l}\text { There is a positive relationship between quality perception and brand } \\
\text { associate. }\end{array}$ & 0.57 & 1.48 & $\sqrt{ }$ \\
\hline 6 & $\begin{array}{l}\text { There is a positive relationship between brand awareness and } \\
\text { distribution intensity. }\end{array}$ & 0.48 & 2.11 & $\sqrt{ }$ \\
\hline 7 & $\begin{array}{l}\text { There is a positive relationship between perception quality and } \\
\text { distribution intensity. }\end{array}$ & -0.11 & -0.56 & $x$ \\
\hline
\end{tabular}

As we can observe from the results of Table 3, there is a positive relationship between quality perception and brand loyalty. In addition, there is a positive relationship between brand awareness and brand loyalty. The third hypothesis of the survey is associated with relationship between brand awareness and quality perception and this relationship has been approved. The result of our survey 
does not provide any evidence to believe that there is any meaningful relationship between brand awareness and brand associate. While the survey provide some support on relationship between quality perception with brand associate, between brand awareness and distribution intensity, our survey did not provide any support for the relationship between perception quality and distribution intensity.

\section{Conclusion}

In this paper, we have presented an empirical investigation to study the effects of various factors including brand associate, brand awareness, distribution intensity and quality perception on brand loyalty. The proposed model of this paper has been examined by designing a questionnaire consists of 16 questions in Likert scale and distributing it among 200 people who implemented a particular brand in mobile industry called Nokia. The results were analyzed using structural equation modeling where Cronbach alpha was calculated as 0.84 . The results have indicated that there was a positive relationship between perception quality as well as brand awareness and brand loyalty. In addition, there is a positive relationship between brand awareness and perception quality.

\section{Acknowledgment}

The authors would like thank anonymous referees for constructive comments on earlier version of this paper.

\section{References}

Buil, I., de Chernatony, L., \& Martínez, E. (2011). Examining the role of advertising and sales promotions in brand equity creation. Journal of Business Research, 66(1), 115-122.

Chen, A. C. H. (2001). Using free association to examine the relationship between the characteristics of brand associations and brand equity. Journal of Product \& Brand Management, 10(7), 439-451.

Field, J. R., Bergiel, B. J., Giesen, J. M., \& Fields, C. L. (2012). Branding: perceptual effects on consumer evaluations. Competitiveness Review: An International Business Journal incorporating Journal of Global Competitiveness, 22(3), 251-260.

Lassar, W., Mittal, B., \& Sharma, A. (1995). Measuring customer-based brand equity. Journal of consumer marketing, 12(4), 11-19.

Lee, J. S., \& Back, K. J. (2010). Reexamination of attendee-based brand equity. Tourism Management, 31(3), 395-401.

Ling, K. C., Piew, T. H., \& Chai, L. T. (2010). The determinants of consumers' attitude towards advertising. Canadian Social Science, 6(4), 114-126.

Valkenburg, P. M., \& Buijzen, M. (2005). Identifying determinants of young children's brand awareness: television, parents, and peers. Journal of Applied Developmental Psychology, 26(4), 456-468

Romaniuk, J., \& Nenycz-Thiel, M. (2013). Behavioral brand loyalty and consumer brand associations. Journal of Business Research, 66(1), 67-72.

Sahin, A., Zehir, C., \& Kitapçı, H. (2011). The effects of brand experiences, trust and satisfaction on building brand loyalty; An empirical research on global brands. Procedia-Social and Behavioral Sciences, 24, 1288-1301.

Tepeci, M. (1999). Increasing brand loyalty in the hospitality industry. International Journal of Contemporary Hospitality Management, 11(5), 223-230. 
Usman, M., Ilyas, S., Hussain, M. F., \& Qureshi, T. M. (2010). General attitude towards advertising: cultural influence in Pakistan. International Journal of Marketing Studies, 2(2), p124.

Yoo, B., Donthu, N., \& Lee, S. (2000). An examination of selected marketing mix elements and brand equity. Journal of the Academy of Marketing Science,28(2), 195-211.

Zehir, C., Şahin, A., Kitapçı, H., \& Özşahin, M. (2011). The effects of brand communication and service quality in building brand loyalty through brand trust; The empirical research on global brands. Procedia-Social and Behavioral Sciences, 24, 1218-1231. 